\title{
Constituents of sustainable development potential of a logistics company
}

\author{
Elena Avdeeva ${ }^{1, *}$, Oksana Belyantseva ${ }^{1}$ and Elena Smorodina ${ }^{1}$ \\ ${ }^{1}$ Voronezh State Technical University, Moscow Avenue, 14, Voronezh, 394026, Russia
}

\begin{abstract}
The article explores the potential for sustainable development of the company in a dynamic environment. The components of the potential are composed of external and internal. For their identification and analysis, tools such as SNW- and SWOT-analysis are used on the example of a construction industry enterprise. It was revealed that internal stability is formed under the influence of management tools. It includes organizational, investment, production, technological and financial sustainability. External stability includes global, regional and national. For a deeper analysis it is desirable to apply the indicator of sustainable development. With its help, it is possible to analyze the development of the enterprise in terms of dynamics, compare different enterprises and identify bottlenecks among the components of sustainable development potential. The indicator is flexible and takes into account industry specifics. The authors concluded that the innovative component should be present in all areas of the enterprise.
\end{abstract}

\section{Introduction}

In today's world, in conditions of constant dynamic development of economic, financial, investment, information-technical, technological and other spheres of society's life, enterprises, like small economic systems, need to adapt to the current changes. The formation of a mechanism for the overall sustainability of the enterprise, which will allow not only to assess the current situation, but also to determine and adjust the strategic and tactical goals of the enterprise is one of the key tasks of management. The subject of the study is the potential for sustainable development of the company in a dynamic environment. The purpose of the study is to identify the components of the enterprise's potential that would ensure its sustainability.

The various aspects of the development problem discussed in the evolutionary, emergent, structuralist and synergetic concepts give grounds to assert that development is a special type of change, thanks to which we have received the world in which we live. I.Prigozhin asserts that the stability of the enterprise as a system implies two states. The first - characterizes the state of equilibrium of the socio-economic system of the enterprise, in which it is in the absence of the influence of factors that disturb. The second state, characterizes the permanent position of the socio-economic system of the enterprise, associated with its cyclical activities and development. With sustainable development, the system returns to a state of equilibrium under any factors influences. The state of instability of the socio-economic system of the

*Corresponding author: avdeeva_ea@mail.ru 
enterprise is characterized by chaotic links of its elements, and in some cases a complete loss of these links and properties [1].

We come to the conclusion that in a broad sense, sustainable development is a development that meets the needs of the present, but does not compromise the ability of future generations to meet their needs. Sustainable development is a development that does not impose additional costs on the next generation; it minimizes negative externalities; ensures a constant simple or extended reproduction of the production potential; it is a development in which humanity needs to live only on interest from natural capital, without affecting itself.

The economic potential of the company's sustainable development includes the potential for sustainability (production, organizational, financial, personnel, market) and development potential, which is the positive dynamics of the components of the sustainability potential plus investment opportunities and innovative development [2]. The economic stability of the state can be achieved with the economic stability of regions and enterprises.

\section{Materials and Methods}

It is advisable to use tools such as SNW and SWOT analysis to analyze the organization's internal environment. The purpose of the SNW analysis is to reveal:

- strengths, advantages of the organization for choosing the development prospects based on them;

- the weaknesses in the organization's activities to overcome them or to take into account their peculiarities in choosing the prospects for development and strategy development;

- neutral components of the organization to find their "transfer" to the category of "strong" and use in developing a strategy. The SNW analysis results are used to identify trends and trends in the elements of the strategy, identify the elements of the strategy as objects of the influence of internal factors, as well as assess and predict the nature of their impact and the possible consequence of these changes as a result. SNW is an analysis of the internal environment for developing a sustainable development strategy for the enterprise. Let's consider the nature of the influence of factors of the internal environment on the structure and content of the enterprise strategy.

When analyzing the organizational structure of management it is important to determine the optimal composition and structure of units, an effective system of links between them and management. The organizational structure can not be a constant, it depends on the growth of the business itself and changes in its market priorities. Often the operating structure of the company differs significantly from the formal, which leads to disagreements and conflicts between departments, the occurrence of "failures" in the entire chain of responsibility and, as a consequence, a decrease in the efficiency of economic activity. The economic security of the enterprise is defined as a process of neutralizing the dangers for security through effective interaction of all elements of enterprise management, that is, the integration of processes of motivation, planning, monitoring, monitoring. Personnel policy and corporate culture are very important for forming human resources, reducing productivity, motivating and stimulating workers, and, finally, organizing specialists with the necessary level of competence and awareness. Formation and development of values and traditions of organization, formulation of priorities [3].

The level of technological efficiency of production should lead to a reduction in the cost of production, to maintain the competitiveness of products and the position of the enterprise in the market, preserving the composition of consumers of products. Increased labor productivity is possible due to the development of logistics technologies, expansion of the market, reduction of material consumption, transport costs, incentives and motivation of employees, etc. Issues of safety of production, labor protection are given a lot of attention. Production hygiene, reduction of the share of harmful production, process automation, 
technical re-equipment of production, labor protection, certification of work places, reduction of the level of injuries, etc. are important. These events will increase the attractiveness of the company for the recruited.

The industrial and social infrastructure is an integral part of their surroundings. It is necessary to improve the conditions of work and rest of employees according to modern trends [4]. In today's realities, with the transition to a digital economy, information technology goes to the forefront.

The application of a number of electronic accounting programs, the main, providing and managing processes, document management, enterprise economic planning, employee accounting, logistics, and accounting of counterparties will significantly increase the company's performance and status. Innovative activities, search for new customers, new materials, additions, technologies, methods and methods of sales, focus on changing the composition of stakeholders [5].

Metrological support is the development of the system for ensuring the quality of products at the stages of development, production and application. Improvement of the metrological quality assurance and monitoring system. Strengthening of entrance control, improvement of metrological equipment, development of cooperation with specialized testing centers and laboratories. A collaborative study of the external and internal environment involves SWOT analysis. Using this method, you can establish links between the strength and weakness inherent in the organization as well as external threats and capabilities. The analysis methodology first involves identifying the strengths and weaknesses, as well as threats and opportunities, and then establishing the chain of links between them, which can then be used to formulate the organization's strategy. The results of the SWOT analysis of the construction organization OOO "GORIZONT-Stroycenter" are presented in Table 1.

Table 1. SWOT analysis for OOO "GORIZONT-Stroycenter".

\begin{tabular}{|c|c|c|}
\hline The inner environment & $\begin{array}{l}\text { Opportunities } \\
\text { 1. The emergence of new } \\
\text { production technologies on the } \\
\text { market. } \\
\text { 2. Implementation of state } \\
\text { programs to provide affordable } \\
\text { housing for the population. } \\
\text { 3. Collaboration with new } \\
\text { developers. } \\
\text { 4. The emergence of new } \\
\text { management technologies and } \\
\text { systems. }\end{array}$ & $\begin{array}{l}\text { Threats } \\
\text { 1. Seasonal work. } \\
\text { 2. Activation of competitive } \\
\text { companies in the region. } \\
\text { 3. Increase in tax burden. } \\
\text { 4. Falling purchasing power of the } \\
\text { population. }\end{array}$ \\
\hline $\begin{array}{l}\quad \text { Strengths } \\
\text { 1. Modern equipment. } \\
\text { 2. High level of automation of } \\
\text { production. } \\
\text { 3. A wide assortment of let out } \\
\text { production. } \\
\text { 4. Qualified and competent staff. }\end{array}$ & $\begin{array}{l}\text { 1. Introduction of new technologies } \\
\text { in the production process. } \\
\text { 2. Implementation of the training } \\
\text { program for using new } \\
\text { technologies. }\end{array}$ & $\begin{array}{l}\text { 1. Improving the quality of } \\
\text { manufactured products. } \\
\text { 2. Development of the service of } \\
\text { additional services on special } \\
\text { conditions in winter time. }\end{array}$ \\
\hline $\begin{array}{l}\text { Weaknesses } \\
\text { 1. Inefficiency of the management } \\
\text { system used. } \\
\text { 2. Low financing opportunities } \\
\text { from own funds. } \\
\text { 3. Low security by working } \\
\text { capital. } \\
\text { 4. Low quality of vertical and } \\
\text { horizontal links in the } \\
\text { organizational structure of } \\
\text { management. }\end{array}$ & $\begin{array}{l}\text { 1. Development and } \\
\text { implementation of a modern } \\
\text { management system. } \\
\text { 2. Participation in the state program } \\
\text { on provision of affordable housing } \\
\text { in the Voronezh region in 2017- } \\
2021 \text {. }\end{array}$ & $\begin{array}{l}\text { 1. Creation of a system of } \\
\text { strengthened control over quality } \\
\text { 2. Rationalization of information } \\
\text { and technical operations at all } \\
\text { levels of the organizational } \\
\text { structure of management. } \\
\text { 3. Conducting marketing } \\
\text { campaigns to stimulate sales. }\end{array}$ \\
\hline
\end{tabular}


The strong sides of the internal environment of OOO "GORIZONT-Stroycenter" are modernized equipment, a high level of automation of production, a wide range of products, as well as qualified and competent staff.

Weaknesses of the internal environment of OOO "GORIZONT-Stroycenter" are low possibilities of financing from own funds, low security of working capital, low quality of vertical and horizontal ties in the organizational structure of management, motivational measures, as well as reduction of efficiency of applied management technologies.

If we talk about the construction industry, then their number increases year by year. In 2000 there were 129340 construction companies, and in 2016 already registered 271604 pieces. There is a sharp decline in state and municipal enterprises from 4140 in 2000 to 1204 in 2016 and the increase in the number of private companies over 16 years in 2.4 times - from 115,331 to 269,548 .

The analysis of entrepreneurial confidence showed that the dynamics of the index of entrepreneurial confidence in construction varies depending on the main indicators of economic development, or rather, the phase of the cycle in which the national economy is located. Averina T. A. writes the respondents attributed high taxes, high cost of materials, structures, products, lack of customers and insolvency of customers, competition from other construction companies, lack of financing along with large interest on the loan. The entrepreneurs are not very concerned about the wear and tear of machinery and equipment, as well as the shortage of skilled workers [6].

\section{Results}

The conducted analysis of the external and internal environment of the organization made it possible to draw the following conclusions. Internal stability is formed under the influence of management tools. It includes organizational, investment, production, technological and financial sustainability. Productivity sustainability is expressed in the ability of the enterprise to resume and improve the production cycle, financial - in the ability to repay its financial obligations to creditors, organizational - in the effective organization of business processes in the enterprise, and technological - in compliance with technological norms and rules.

Under external stability we understand the external factors of the environment, which have a positive impact on the enterprise. It includes global, regional and national sustainability. Potential sales of an enterprise in a competitive environment, market capacity characterizes market resilience [7].

Dynamic stability consists in a favorable positive change in investment activity, growth of sales volumes, improvement of qualifications and working conditions of employees, introduction of innovations and $\mathrm{R} \& \mathrm{D}$, professional development of employees, introduction of electronic programs, etc. Increasing volumes of sales, entering new markets, attracting large wholesale customers involves getting more and more profits, which is the source of the company's development, creating an accumulation fund that raises the cost of the enterprise itself. But sales growth must necessarily be accompanied by the effective utilization of all resources of the company, the qualitative indicators should increase. At the same time, additional costs associated with additional capacity loading - marketing, marketing, increased competitiveness, personnel, etc., are necessarily incurred. Here, the existing economic potential is important, which is to ensure the sustainable development of the company [8].

Let's consider the coefficient of sustainable development of enterprises, proposed by A. A. Almazova [9] and adjusted for sectoral development. It will have the following form:

$$
\mathrm{ISD}=(\mathrm{SP}+\mathrm{RP}+\mathrm{IFP}) * \mathrm{OP} * \mathrm{IS}
$$

where SP - is the personnel potential, calculated as the proportion of employees engaged in research and development, in the average number of employees of the enterprise; 
RP - scientific potential, representing the sum of the share of intangible assets and the results of research and development in the assets of the enterprise;

IFP - Production potential and financial potential - We count on the overall profitability of the company;

OP - expert assessment of organizational-management potential on a scale scale from 0 to 3 ;

IS is the level of industry development (five main indicators of the level of branch development are introduced in a low, moderate, average, elevated, high. For each value, we assign the weight coefficient: low - IS $=0.5$, moderate - IS $=0.75$, mean IS $=1$; elevated - IS $=1.25$ and high - IS $=1.5$ ).

A high level of industry development is assigned to the industry, if it sustainably occupies a certain market segment, has a widely diversified network of solvent suppliers and consumers, is characterized by steady growth dynamics.

An advanced level of industry development is attributed to the industry in the case when the companies of the industry are stable occupy a leading position in the industry, but are closed to a limited number of suppliers and consumers, or the data of the companies are in a stable position, but there is an aggressive position of the competing industries. The average level of sectoral development is typical of an industry whose company occupies a leading position in the industry and the region, but there are difficulties in interaction with contractors or the industry is characterized by unsustainable dynamics of development. A moderate level of industry development is assigned to a sector that demonstrates a steady negative dynamics if there are high risks from the competition policy of other industries or there are other threats. The low level of industry development is characterized by the unstable situation that companies occupy both in the industry and in the regional market, also with a strong dependence on insolvent suppliers and consumers and a high level of competition. Using the described coefficient, one can analyze the development of the enterprise in dynamics, compare different enterprises and identify bottlenecks among the components of the potential for sustainable development. The indicator is flexible and takes into account sectoral features. It can be easily adapted to any industry specificity. The practical significance of the developed coefficient is that it estimates the conduct of economic activity in general.

\section{Conclusions}

All components of the company's potential ensure its sustainability with a certain frequency is considered by Sidorin A.V. [10]. The approximated wave-shaped trajectory of enterprise development presented in Fig. 1 is an alternation of "stimulated" by innovations of waves with phases: reengineering-kaizen-recession. Thus, during a time interval T0-T1, an enterprise's activity is characterized by the value E0 of the efficiency of its activity or some other indicator (the volume of sales, profits, indicators of labor productivity, etc.).

This level is kept at a minimum during the time interval T0-T1, including at least kaizen, including at least kaizen, and at the very best - constantly rising. Innovations and the requisite reengineering in the process lead to a T1-T2 business with a significantly higher E10 efficiency that is held in the "kaizen" mode during the time interval T2-T3 in the "kaizen mode" or constantly, but not as radically as the reengineering means, is raised to the values of E11, and then somewhat reduced to the value of E12 so that in the "mode" kaizen hold for the time T3-T4.

Among the many possible reasons for the decline in efficiency is the company's loss of its exclusivity and competitive advantages from the sale of its innovative products, which has been developed after some time and by competitors. 


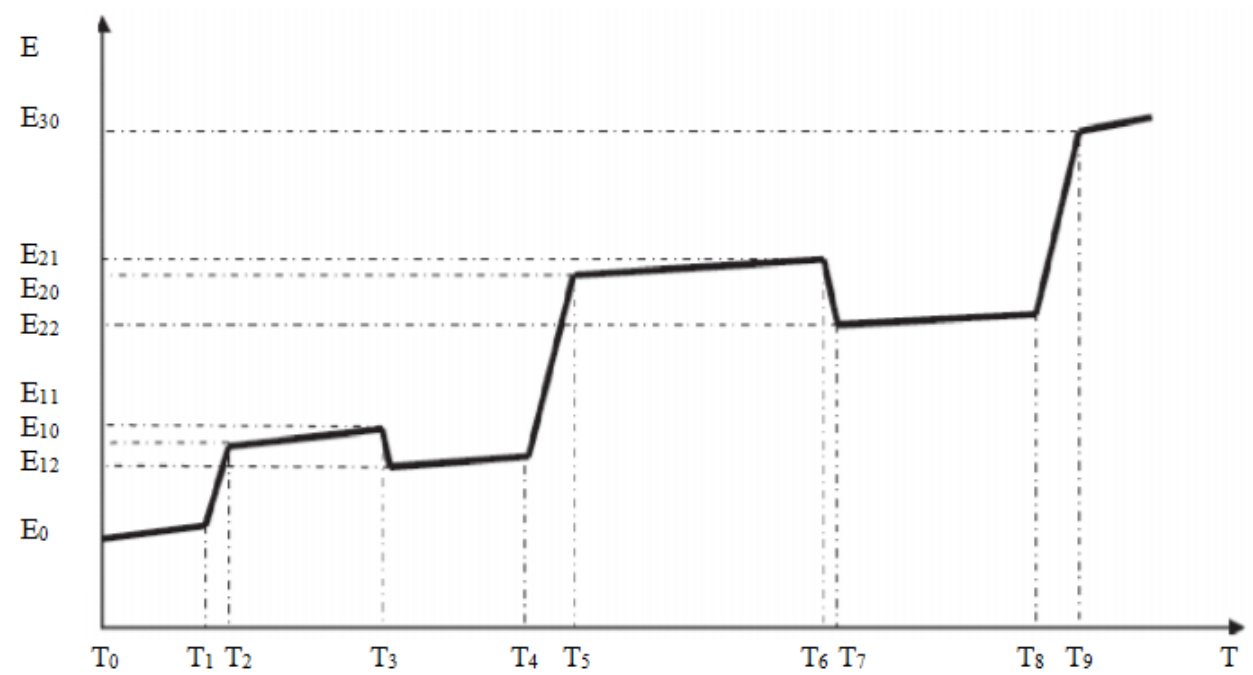

Fig. 1. A wave-like trajectory of enterprise development based on innovations as a set of phases of reengineering and kaizen.

Then, realizing the need to "tear off" competitors, the enterprise during the time T4-T5 goes with the next innovative product to an even higher level of E20, raising it in the "mode" kaizen during the time T6-T7 to the level of E21, then to for the same reasons, including with a competitive environment, it dropped to some value E22 and was held during the time of T7-T8 to the next innovation in the time T8-T9. And so - until the "excitement" of the next wave of another innovation and reaching the level of E30. [10].

Thus, the innovative component should be present in all spheres of activity of the enterprise.

\section{References}

1. S.M. Vdovin, Strategy and mechanisms of sustainable development of the region, Monograph (Infra-M, Scientific Thought, Economy, 2015)

2. E. Avdeeva, T. Averina, L. Kochetova, E3S Web of Conference, 03013 (2018)

3. T. Averina, E. Avdeeva, O. Perevalova, Network of conferences MATEC 170, 01121 (2018)

4. K.Yu. Belousov, Problems of modern economics 4(48), 418-422 (2013)

5. O.M. Belyantseva, S.V. Belyaeva, S.S. Uvarova, Modern economy: problems and solutions 11(59), 91-96 (2014)

6. T.A. Averina, E.A. Avdeeva, Economics and management of the control system 16-2.2, 208-214 (2015)

7. S. Kovalev, E. Smorodina, Ya. Rogacheva, O. Vasilyeva, MATEC Web of Conferences 106, 08038 (2017)

8. E.A. Avdeeva, T.E. Davydova, Economics and Entrepreneurship 10-1(87-1), 94-96 (2017)

9. A.A. Almazova, Strategic Management of Sustainable Development of Enterprises in the Nuclear Industry: Thesis for a Candidate Degree in Economics (N. Novgorod, 2014)

10. A.V. Sidorin, V.V. Sidorin, International Journal of Applied and Fundamental Research 9-2, 35-40 (2014) 